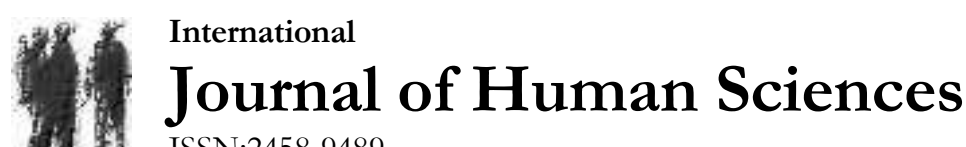 \\ ISSN:2458-9489
}

Volume 16 Issue 1 Year: 2019

\section{Expected functions of an effective child justice system administration? A framework developed through a qualitative study in Turkey}

\author{
Hasan Buker ${ }^{1}$ \\ Sebahattin Gultekin ${ }^{2}$ \\ Alper Akgul ${ }^{3}$
}

\begin{abstract}
Research problem / aim: Turkey initiated its first specialized child court in 1987, but the most visible improvements towards establishing child-specific judicial procedures were only achieved in 2005, when the Child Protection Law (CPL) became effective. This Law required the involvement of several agencies in both providing protection for children and adjudicating them when they were involved in delinquency. After this Law was enacted several comprehensive projects were carried out, different institutions were established, and different legal and policy changes took place to maintain the effective administration of child justice procedures. Yet, practical observations of these different stake holders indicated that a useful, productive, and cohesive system in coordinating these various agencies involved in the child justice system procedural processes was not fully achieved as of 2016. The primary objective of this study was to develop a framework on how an effective child justice administration system should be established and what kinds of functions it should carry out in Turkey.
\end{abstract}

Method: This study, first of all, provides an analysis of the existing practices and procedures of the various agencies involved in administering child justice procedures through a series of systematic observations, as well as focus group and in-depth interviews with key informants.

Findings: The findings of this study yielded propositions on the general principles, functions, and the bureaucratic nature of such system that can increase the overall effectiveness of the outcomes of the juvenile justice processes.

Conclusion: This study concludes with a discussion of how the study findings should be utilized in both the Turkish and international contexts.

Keywords: Child Justice; administration; systems approach; interagency coordination; juvenile; Turkey.

\section{Introduction}

Providing for the best interests of children is the major responsibility and task of the government when children fall in conflict with the law and when they are in need of protection. The Child justice system (CJS, hereafter) is the essential component of the government that is entrusted to accomplish this important task in an effective and efficient manner. The CJS is comprised of different agencies, professionals, and regulations. The elements of this pluralistic and

\footnotetext{
${ }^{1}$ Assos. Prof., Dr. Minot State University, ND USA, hasan.buker@minotstateu.edu

${ }^{2}$ Dr., Researcher. Global Policy and Strategy Association. USA, sebahattingultekin@gmail.com

${ }^{3}$ MA, Doctoral Student at Gazi University, Ankara, Turkiye, alakgul@gmail.com
} 
Buker, H., Gultekin, S., \& Akgul, A. (2019). Expected functions of an effective child justice system administration? A framework developed through a qualitative study in Turkey. Journal of Human Sciences, 16(1), 87-101. doi:10.14687/jhs.v16i1.5452

fragmented system, nevertheless, must act together through a cohesive strategy to be able to provide solutions that are in the best interest of each and every child who passes through this system by undoing the harms involved, providing protection, and staying away from a classical punitive perspective. This intricate, yet, indispensable responsibility of the CJS can only be achieved through effective and efficient administrative structures and strategies in any given country.

In this respect, Turkey needs establishing and maintaining an effective administrative strategy in the realm of the CJS. Turkey has made significant advances in developing a comprehensive CJS in recent years. Although earlier efforts to this effect started as early as 1978, with the enactment of a law to establish the child courts, the first child court was established in 1987. Nevertheless, the availability and the functions of these specialty courts started to be diffused around Turkey more discernably after 2005 upon the enactment of the Child Protection Law (CPL). Since then, the number of child courts has been increasing and the other agencies relevant to providing justice to children (social services, child protection, law enforcement, and correctional facilities) have been developing their capabilities.

Yet an effective CJS requires more than enacting laws, establishing courts, and relevant institutions. Several extensive projects were carried out to strengthen the effectiveness and efficiency of the CJS in Turkey during which a significant amount of material was developed and a substantial number of professionals were trained (Children First and Justice for Children projects were some important examples which were carried out with the support of UNICEF, EU, and the participation of a group of different stake holders in Turkey). The CJS, along with the overall Child Protection System, however, still faces several challenges; the most prevalent of which might be counted as the legal controversies, lack of civil involvement, inefficient (or, non-existent) management of the overall CJS, and ineffective coordination and cooperation among the agencies, which are either directly or indirectly involved in procedures of the CJS. An important step towards overcoming these challenges should be working towards developing a precise administrative structure for the CJS of Turkey at the political level.

Based on the aforementioned concerns and facts, the overall objective of this study was to conduct a survey of existing procedures and policies relevant to child justice processes and to explore the perspectives of key informants taking active role in these processes in order to develop a set of recommendations towards establishing and maintaining an effective administrative structure for the child justice system in Turkey. The findings of this particular study can also be extended beyond the borders of Turkey where similar problems in the complexity of the juvenile/child justice procedures and policies are being experienced at different levels.

This study was especially timely owing to the fact that the child justice processes in Turkey had recently been immersed in a rapid developmental process. With so many new rules that were introduced and developed, the expected efficiency and effectiveness in carrying out the desired child justice processes required effective organization, planning, evaluation, development, and coordination. These needs could only be achieved through the presence of a functional administrative system.

This paper starts below with an overview of the agencies and processes involved in the child justice system in Turkey. The remainder of the paper provides a description of the methodology, a discussion of the findings and the conclusion as to how to interpret the results of this reported study.

\subsection{An Overview of the Child Justice Processes in Turkey}

For the purposes of this study, the term "child justice" was used to refer to those judicial processes that are related to the decisions to be made about children when they are in need of protection and when they are suspected of a delinquent act. An overall assessment of these processes, therefore, covers legal provisions and institutions taking part in carrying out adjudication 
Buker, H., Gultekin, S., \& Akgul, A. (2019). Expected functions of an effective child justice system administration? A framework developed through a qualitative study in Turkey. Journal of Human Sciences, 16(1), 87-101. doi:10.14687/jhs.v16i1.5452

as well as protection measures. In this regard, the overall child justice processes in Turkey can be examined using two major tracks: the protection track and the adjudication track.

\subsubsection{The Protection Track}

According to the CPL, one of the major responsibilities of the child courts is to make determinations about the need for protection of a child and to order any specific protective/supportive measure(s). There are five types of these measures included in the CPL: Care, sheltering, education, health, and consultation. The CPL also determines which agency should implement these measures. The Child Court Judge is responsible for monitoring the implementation of these measures and can order a process of supervision be put in place during the implementation of these measures. During the decision making process, the Child Judge has to seek the opinion of a social worker in order to make an appropriate determination. The referral for the court's action can come from the child, his/her family, the prosecutor, law enforcement, public officials and Ministry of Family and Social Policy (MoFSP) institutions. Figure 1 illustrates the process and actors in this track.

The existing judicial system does not assign any specific responsibility to the child courts to deal with victimized children. A victimized child, hence, can appear before a regular court when the offender is not a child (under the age 18). Yet, the overall objective of this study required understanding which agencies and professionals take part in the child victimization cases due to the fact that an all-inclusive child justice administration should also be concerned about their interaction with victimized children.

In child victimization cases, public officials are considered mandatory reporters according to the CPL, but regular citizens can also report the case to the law enforcement agencies. Starting from that point; law enforcement, prosecution, forensic examiners, social workers, and, in the recent years, professionals in the Child Monitoring Centers (CMC) are commonly involved in these cases.

The CMCs are a relatively recent institution in the system and are not wide spread around the country. They provide a sort of "one-stop shop" service especially for sexually abused children by providing a special setting for carrying out the forensic interview as well as other processes through a multi-disciplinary team approach. Figure 2 demonstrates the actors taking place in the child victimization case processing.

\subsubsection{The Adjudication Track}

In addition to the protection track, the child justice system in Turkey covers the adjudication of delinquent children. In this regard, the CPL specifies the responsibilities of the courts and prosecutorial offices in dealing with the delinquency cases. In this track, the law enforcement procedures, the prosecutor offices and the courts are all child-specific. A delinquency suspect will go through the special units and facilities of law enforcement, prosecution, and adjudication according to the current practices of the child justice in Turkey (Kirimsoy, et al., 2013).

In addition to these main actors, counselors, social workers, and probation/parole officers carry out important responsibilities in the adjudication track of the child justice in Turkey (Cocuk Adaletinde Surec Akis Semalari, 2014). 
Buker, H., Gultekin, S., \& Akgul, A. (2019). Expected functions of an effective child justice system administration? A framework developed through a qualitative study in Turkey. Journal of Human Sciences, 16(1), 87-101. doi:10.14687/jhs.v16i1.5452

Figure 1. Protection track of child justice processes

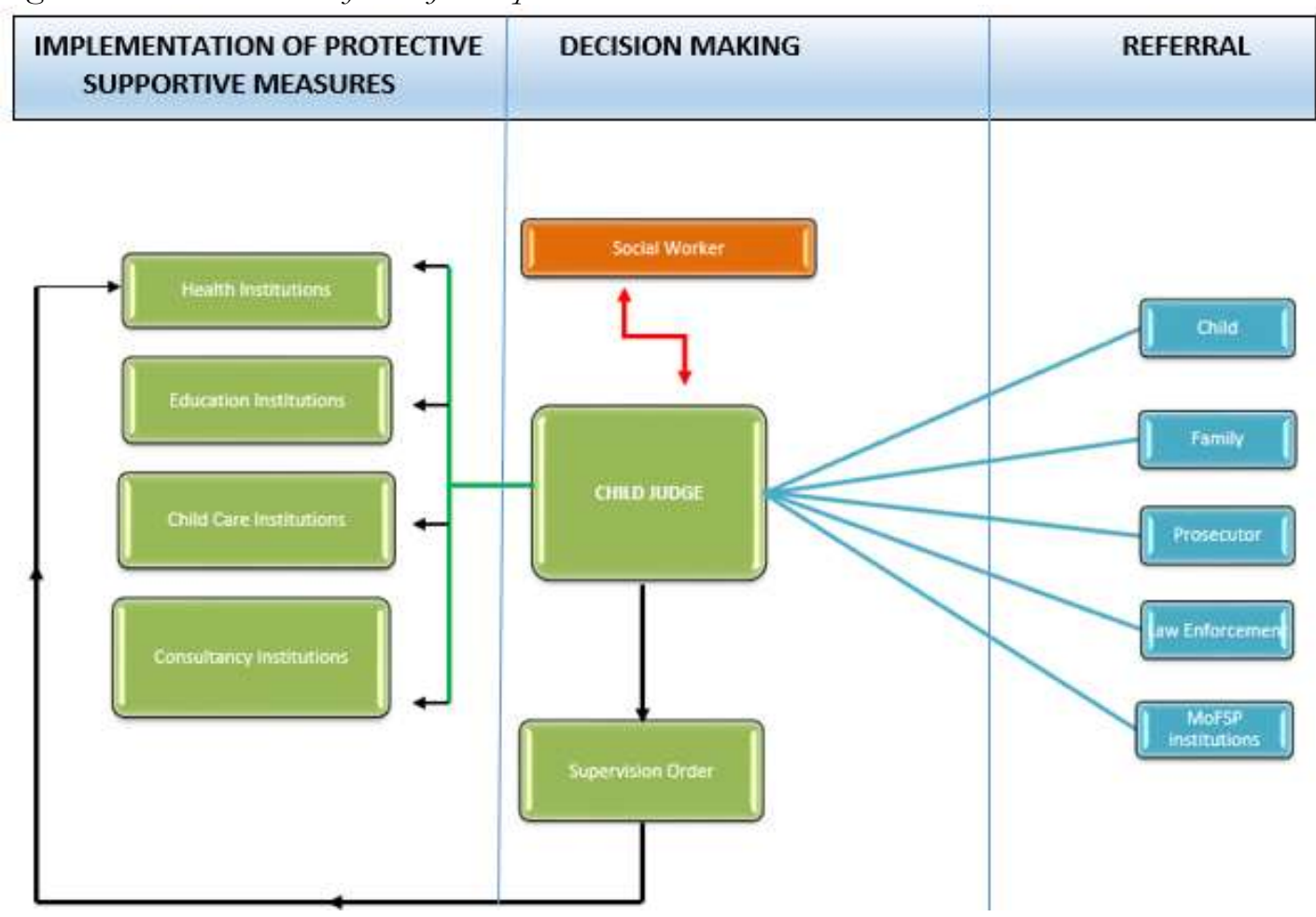

Figure 2. Agencies / actors taking part in the judicial processes in child victimization cases
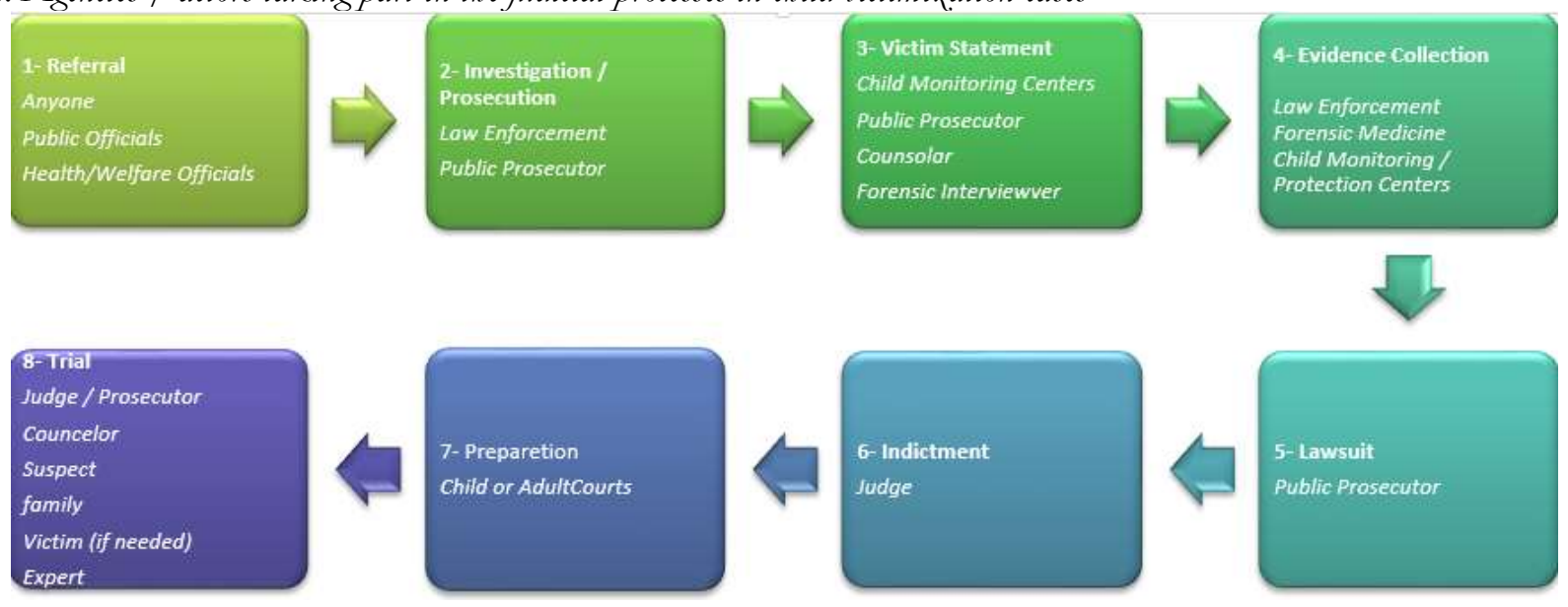

\subsection{Problem Statement:}

As described above, the processes relevant to child justice in Turkey mainly involve both adult and child courts as well as child-specific and general law enforcement, prosecutorial offices, medical examiners, correctional institutions, social services, and legal counselling (lawyers). Since the establishment and operations of these agencies with different bureaucratic backgrounds and professional perspectives had been relatively recent in Turkey, establishing a structure and work culture to bring these agencies to work horizontally together towards globally recognized goals of child justice had proven to be a challenge. As a response, several projects have been developed and implemented since 2006 and one of the most recent of these projects produced a strategy document and training materials (Cocuk Koruma Hizmetlerinde Koordinasyon Strateji Belgesi - 
Buker, H., Gultekin, S., \& Akgul, A. (2019). Expected functions of an effective child justice system administration? A framework developed through a qualitative study in Turkey. Journal of Human Sciences, 16(1), 87-101. doi:10.14687/jhs.v16i1.5452

CKHKSB, 2013) followed by an extensive training program including professionals from the relevant agencies. XXX and XXX, the author and one of the co-authors of this paper, played an active role in this project as consultants and trainers.

Figure 3. Agencies / actors taking part in the judicial processes in delinquency cases

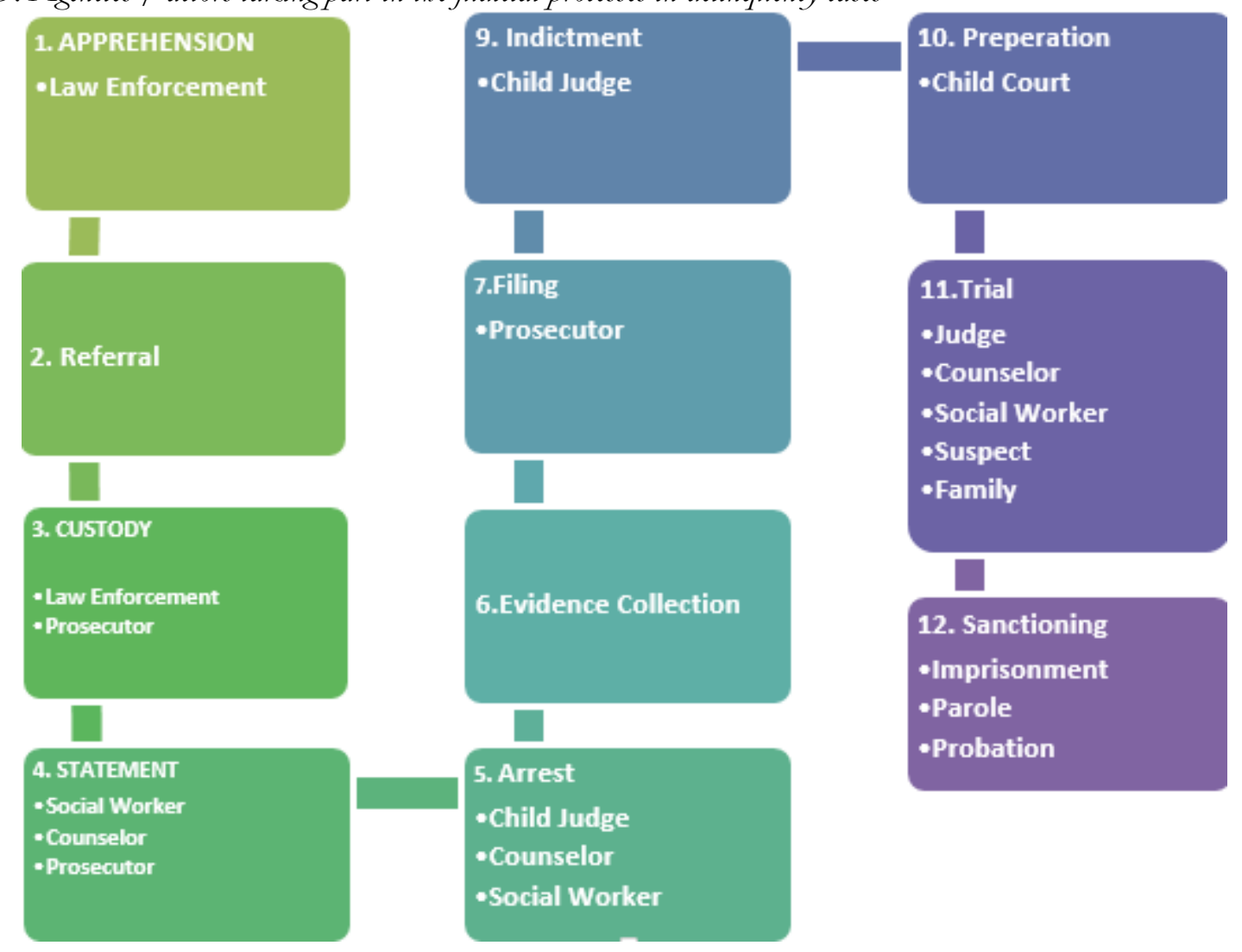

In addition to that challenge, the Turkish public administration system had undergone significant changes in 2011, during which the MoFSP was established and several responsibilities, which were initially defined for the Ministry of Justice when the CPL was enacted in 2005, were transferred to that new Ministry (i.e., managing the secretarial responsibility of Central Coordination activity). In addition to these new responsibilities, MoFSP also started to develop its own structures with the inclusion of brand new institutions designed to take care of and rehabilitate children who were victimized, in need of protection, or involved in delinquency, but not found to be criminally liable. In addition to the changes in these two major Ministries, the law enforcement, medical, and educational institutions had also faced a challenge to fulfill their responsibilities given by the CPL and the required increasing intensity of the problems that called for the improved actions of the child justice institutions.

Finally, Turkey was suffering from a lack of public awareness as well as from a limitation of knowledge and necessary skills of professionals involved in the newly introduced child justice processes (TBMM, 2010; T.C. Cumhurbaskanligi Devlet Denetleme Kurulu, 2013; UNICEF, n.d.). This situation had mainly entailed an inefficient flow of these processes as well as dissatisfaction with their outcomes

This research study was conducted to examine the existing child justice processes in Turkey and to develop a set of policy recommendations for establishing a new administrative structure in the child justice system of Turkey. This new change was expected to help to systematize the child justice processes towards being more effective and efficient in producing projected outcomes as 
Buker, H., Gultekin, S., \& Akgul, A. (2019). Expected functions of an effective child justice system administration? A framework developed through a qualitative study in Turkey. Journal of Human Sciences, 16(1), 87-101. doi:10.14687/jhs.v16i1.5452

stated in both internal legal regulations and in international treaties to which Turkey is a signatory, such as the UN Convention on the Rights of the Child. This manuscript reports the findings of the authors, who were contracted as consultants based on this issue, regarding how to frame this administrative function in the context of the child justice processes.

\section{Methods}

This manuscript reports the findings of two major data collection strategies:

On-site visits and observations: After completing the training programs and the policy document on increasing the effectiveness of interagency coordination and cooperation in child protection/justice processes (Cocuk Koruma Hizmetlerinde Koordinasyon Strateji Belgesi - CKHKSB, 2013), XXXX and XXXX along with several other colleagues, visited ten different provinces in Turkey. During these visits, the authors had an opportunity to meet and discuss issues with 127 different key informants from the agencies (as indicated above) and who were participating in child justice processes. During these observatory visits and interviews, rubrics were used to evaluate the activities of the agencies and main actors. Table 1 includes a set of measures that were included in those rubrics.

Table 1. A group of measures/ indicators included in the evaluation rubrics

\section{MEASURE}

Current administration of the agency is aware of the new coordination model and the Strategy Document

Practitioner level participants of the training from this agency have still been holding their relevant position (to the child protection field)

Administrator(s) of the agency has been participating in the provincial coordination meetings

The requirements of the protective and supportive measure decisions (implementation plans, followup plans, etc.) given according to the Law No: 5395 have been done by the agency

An effective coordination and cooperation have been carried out with other relevant agencies in implementing the protective and supportive measure decisions (implementation plans, follow-up plans, etc.) given according to the Law No: 5395

The agency has been recording the statistical data in regards to the protective and supportive measure decisions

The agency is result-oriented and following-up on the goals of the Strategy Document

Provincial Coordination Secretariat Office is created

Governorship is sensitive enough and acting responsibly towards solving the problems in the field

The court is monitoring the implementation of the protective and supportive measures and intervening the implementation process when deemed necessary

A generally positive and constructive attitude is available at the courts

Judges, prosecutors and social workers of the courts are in connection with the other actors

In-depth and focus group interviens: Another major data collection strategy of this study was conducting in-depth and focus group interviews. Focus group interviews were carried out in three sessions in which 87 professional taking part in the child justice processes participated. These participants were selected by their respective governmental agencies to participate in the study. However, they were provided anonymity in answering the questions and they were informed that participating in the study was voluntary. In addition to these focus group interviews, 12 individual professionals were interviewed extensively. Likewise, the participants of the interviews were also informed about anonymity and voluntary participation principles. The guide employed during these interviews is presented below as Table 2 . 
Buker, H., Gultekin, S., \& Akgul, A. (2019). Expected functions of an effective child justice system administration? A framework developed through a qualitative study in Turkey. Journal of Human Sciences, 16(1), 87-101. doi:10.14687/jhs.v16i1.5452

Table 2. The guideline for the interviews

\section{Goal / Problem / Question}

1. Assessing the participants' perceptions regarding the existence of a systematic work approach with determined goals and in pursuit of the principle of the best interest of children

- Is there an understanding of a child justice "system" among the institutions and professionals who take part in the processes of the child justice?

\section{Subsequent Questions}

- Are you capable of observing and/or comprehending what your role means in the total process of child justice?

- What is your understanding/knowledge of the other institutions'/professionals' role?

- Can you perceive yourself/institution as a part of a complete system?

- How often do you experience/feel that there is a goal conflict between you and the other institutions/professionals in the child justice?
2. What are the needs to develop a system approach among the institutions taking part in child justice?
- (In connection with the questions of the first section) What are the root causes of the goal conflicts?

- What is the level of effectiveness and the efficiency of the interagency coordination and communication in child justice?

- What are the requirements to develop the quality of interagency coordination and communication in child justice?
3. What is the mission and the vision of the child justice?
- What is your professional and institutional perspective regarding the question of "what is justice for children?"

- In this regard, what are the conflicting and concurrent views of the stake holders, including the general public
4. Assessing the available planning and strategy development capacity regarding the child justice processes
- Is there a child justice policy/plan/strategy?

- If so, how does it affect your agency?

- If not, what are the overall institutional approaches on child justice (Does your agency have plans on this issue? What are the implications?)

- What is the role of non-governmental organizations? (Can they actively participate in developing strategies?)

- Is there a need to develop a national strategy? If so, how and by which agency can this strategy be developed?

- What is the local capacity to contribute to the long-term planning efforts especially regarding preventive strategies? Is there an effective communication between the local agencies and central-level decision makers? What are the needs for a more effective bottom-up decision-making process? 
Buker, H., Gultekin, S., \& Akgul, A. (2019). Expected functions of an effective child justice system administration? A framework developed through a qualitative study in Turkey. Journal of Human Sciences, 16(1), 87-101. doi:10.14687/jhs.v16i1.5452

\begin{tabular}{|c|c|c|}
\hline $\begin{array}{l}\text { Accountability, } \\
\text { performance } \\
\text { measurement }\end{array}$ & $\begin{array}{l}\text { responsibility, } \\
\text { indicators, and }\end{array}$ & $\begin{array}{l}\text { - What is the current capacity to determine and revise the } \\
\text { ineffective practices? What are the personal experiences } \\
\text { of the participants? } \\
\text { - What is the likelihood of determining the responsible } \\
\text { parties in the cases of deficiencies and failures in the } \\
\text { processes? What is the possible response of the current } \\
\text { administrative structures in this case? } \\
\text { - What are the needs to further clarify the roles and } \\
\text { responsibilities and to strengthen the accountability } \\
\text { mechanisms? }\end{array}$ \\
\hline $\begin{array}{l}\text { Innovation, } \\
\text { development }\end{array}$ & research & $\begin{array}{l}\text { - Do you need an innovative and reformist approach to } \\
\text { reduce the difficulties that you experience in your daily } \\
\text { practices? What are the opportunities and needs for } \\
\text { developing such an approach for the child justice } \\
\text { - How do you perceive the effectiveness of the existing } \\
\text { efforts (if any) to develop the existing structures, } \\
\text { human resources, and legal regulations regarding child } \\
\text { justice? What are the needs? }\end{array}$ \\
\hline $\begin{array}{l}\text { Assessing the } \\
\text { administrative } \\
\text { justice }\end{array}$ & $\begin{array}{l}\text { need for a new } \\
\text { agency in child }\end{array}$ & $\begin{array}{l}\text { - What kind of an administrative structure should be } \\
\text { developed, according to your professional perspective, } \\
\text { to carry out the aforementioned administrative functions } \\
\text { (i.e., developing a system approach, developing and } \\
\text { maintaining a mission and vision, strategic planning, } \\
\text { innovation/development, accountability) }\end{array}$ \\
\hline
\end{tabular}

The data collected during these two main strategies was processes as visualized in Figure 4.

\section{Findings and Discussion}

The analyses of the qualitative data yielded three main themes on how a new and effective juvenile justice administration should be formed and how it should function in dealing with the challenges faced existing practices of the child justice system in Turkey:

- Propositions on general principles and overall approach to the problem.

- Propositions on the functions of an effective administration of the child justice system.

- Propositions on the bureaucratic nature of a new administrative structure.

3.1. Propositions on the General Principles and Overall Working of an Effective Administrate Structure.

Under this theme, first of all, the data indicated that the determination to address and resolve the problems facing child justice practices in Turkey was timely and necessary in order to uphold those efforts directed towards establishing and maintaining an effective administrative structure in that context. Aforementioned projects, policy changes, training programs, and the introduction of new institutions and practices were all taken as indicators of the willpower that existed among Turkish officials and their counterparts. In addition to their overall motivation and determination, the following were discovered during this research effort in terms of what the overall approach and principles should be. 
Buker, H., Gultekin, S., \& Akgul, A. (2019). Expected functions of an effective child justice system administration? A framework developed through a qualitative study in Turkey. Journal of Human Sciences, 16(1), 87-101. doi:10.14687/jhs.v16i1.5452

Figure 4. The data analysis spiral

\section{Procedure / Implication in the Current Study}

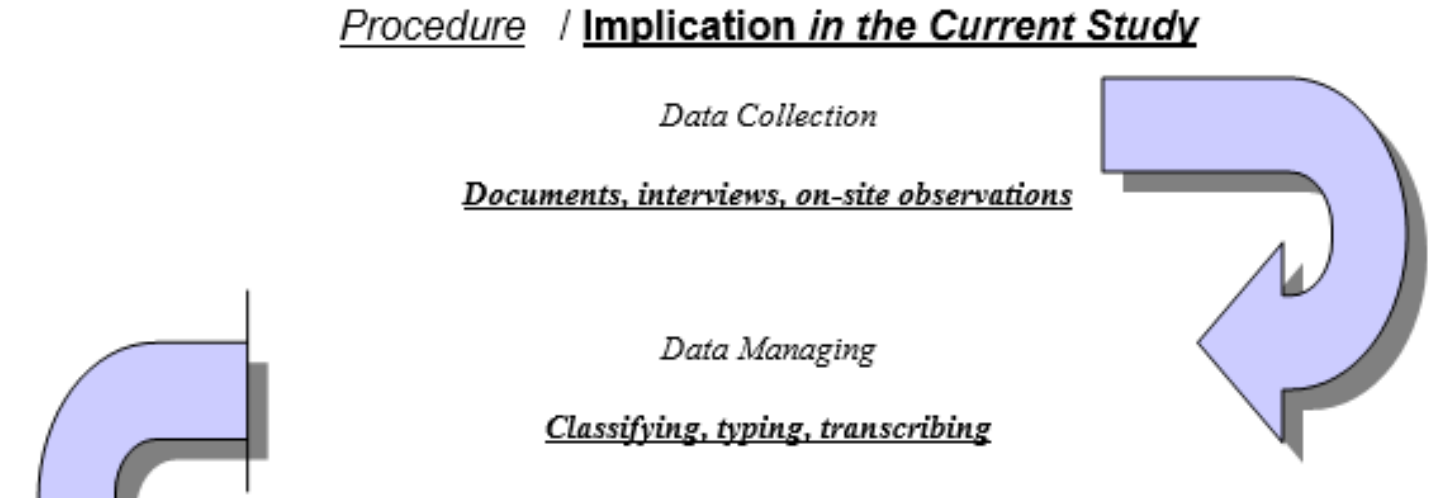

First Examination

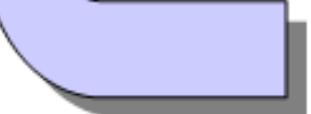

Open coding, axial coding, finding particular themes
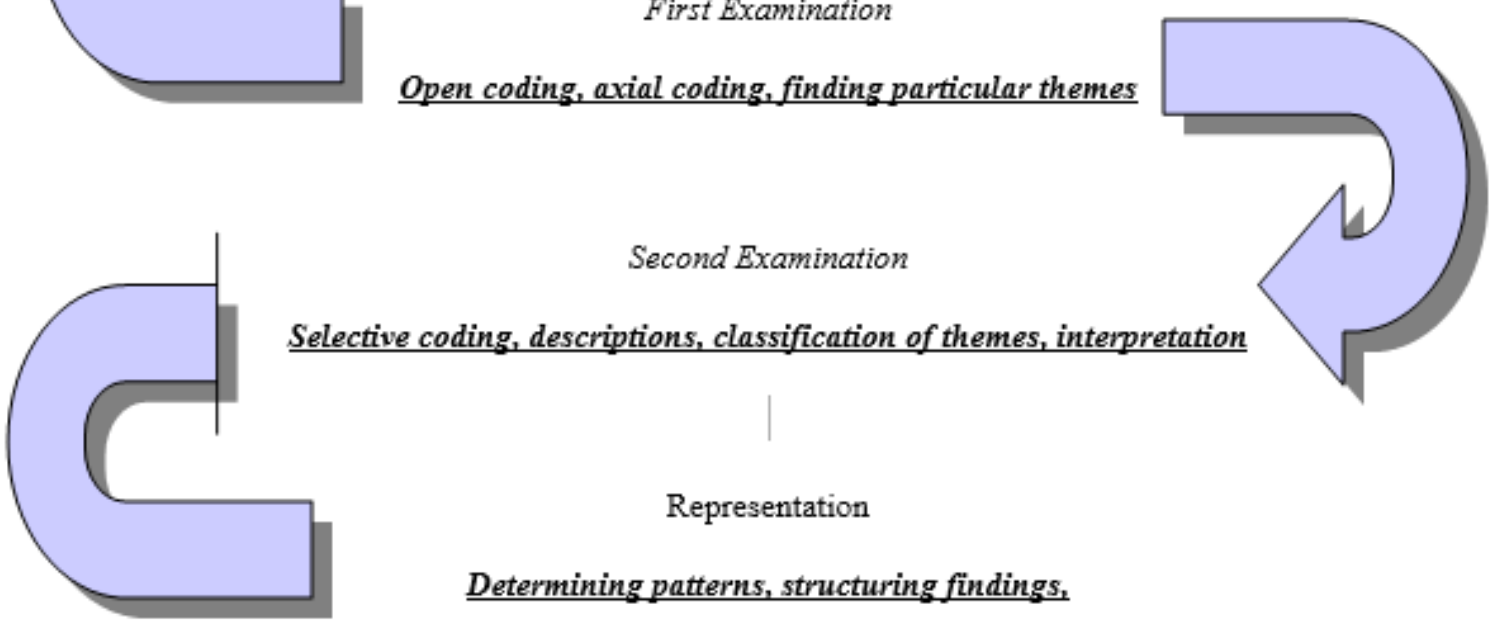

Second Examination

Selective coding, descriptions, classification of themes, interpretation

Representation

Determining patterns, structuring findings,

somparisons, discussion of the findings

3.1.1. Institutionalizing the administration and its functions: Turkey's past and existing efforts in addressing the problems regarding child justice revealed that understanding change only in terms of law/policy making would entail another "dead end" for the practitioners. The data indicated that new legal regulations and/or policy documents without an effective administrative function to plan, evaluate, enforce, and revise these written regulations would not create the expected change in child justice processes. In short, the administrative functions in child justice should be institutionalized in a way that it would ensure that the laws/policies would fulfill their end goals.

Another sub-theme connected to this one was regarding what actually was expected from that administrative structure. In general, the relevant literature indicates that the classical functions of the administration include planning, organizing, human resourcing, directing, coordination, reporting, budgeting, and controlling (Dimock \& Dimock, 1983; Fayol, 1949; Gulick, 1936). The following sub title (3.2) will reflect in detail how the functions of the expected administrative structure should be designed based on the findings of this study.

The data also indicated that a new administrative structure should distance itself from carrying out the day-to-day procedures of the child justice system. Instead, it should be focused on its administrative functions as indicated above.

3.1.2. Adopting a system perspective: The data collected throughout this research effort indicated evidently that the agencies, processes, actors, and legal regulations regarding child justice were not constituting a "system" in the Turkish context and a significant founding principle of a 
Buker, H., Gultekin, S., \& Akgul, A. (2019). Expected functions of an effective child justice system administration? A framework developed through a qualitative study in Turkey. Journal of Human Sciences, 16(1), 87-101. doi:10.14687/jhs.v16i1.5452

new administrative perspective/structure should be focused on establishing and maintaining a systems approach.

A "system" is generally understood as an interrelationship of relevant units and their subunits and can be considered to be more than the sum of its basic individual units (Kahn \& Katz, 2010). Accordingly, a system consists of units and subunits, there is a constant interrelation among these units, and without that interrelation a system cannot survive. Finally, these units can constitute a "closed system" or an "open system." Open systems are represented by social organizations, an example of which can be the child justice system, and these systems are in constant interactions with the factors / units surrounding them (their ecology) (Bertalanffy, 1968). In the systems perspective, mutual goals, all-inclusive perspective, and interaction are vital elements (Kahn \& Katz, 2010).

Combining this theoretical perspective with the data yielded the following recommendations for an effective child justice "system" administration in Turkey:

- A mutual goal for the child justice system should be determined by all internal units/subunits, and the external constituencies of this system.

- The system should prioritize this goal over the goals of its units to maintain a holistic practice.

- The responsibilities of each unit within the system should be precisely defined to reach this goal.

- A unit in the system should be devoted to administrative functions.

- A reliable and open communication channel should be established and maintained among the units and with external constituencies.

- The system should position itself as "open," define its external constituencies, understand their expectations, and elucidate its own capacity in clear terms.

- As an open system, the inputs needed from external sources and the outputs to be produced should be defined and mutually agreed upon.

3.1.3. Child-Centered and Rights-Based Practices: The data collected throughout that research indicated that the existing child justice practices in Turkey had long departed from its original focus; which was the children and their rights. According to the participants, most of their practices were geared towards completing one or another process as required by the superficial requirements of the legal regulations. In most of these activities, furthermore, a through consideration of "the best interest of the child" was not fully visible. The existing practices were not going beyond conventional punitive approaches for delinquent children, for instance.

Conclusively, the data suggested that the administrative structure in the child justice system should be structured and should function based on the fundamental principle of being focused on the best interest of the children, more than anything else.

This understanding also concurs with the new public management approach which requires public organizations to be focused on the demands and expectations of their "customer," just like business organizations. This approach, furthermore, requires being flexible for the internal and external demands, evaluating success based on "customer" satisfaction, decreasing bureaucracy, a multidisciplinary approach, and staying away from short-term populist movements (O'Leary, 2010).

3.1.4. Sustainability: A final recommendation derived from the data for the general working principles of the proposed administrative structure in the Turkish child justice system is about maintaining sustainability in this new structure. In the past decade, Turkey had completed many projects regarding child justice with internal and external sources. Throughout these projects, numerous documents were developed (such as strategy and policy documents (Cocuk Koruma Hizmetlerinde Koordinasyon Strateji Belgesi - CKHKSB, 2013), many training programs were carried out for the practitioners working in the child justice procedures, and several new institutions 
Buker, H., Gultekin, S., \& Akgul, A. (2019). Expected functions of an effective child justice system administration? A framework developed through a qualitative study in Turkey. Journal of Human Sciences, 16(1), 87-101. doi:10.14687/jhs.v16i1.5452

and practices were introduced. These activities outwardly represented achievements with certain limitations. Nonetheless, most of these achievements had not been sufficiently sustained to become institutionalized or to impact the quality of the outcomes of the child justice procedures as of the time of this research.

For instance, XXX, the authors of this research paper, acted as lead consultants for one of these earlier projects in which a strategy document was developed (Cocuk Koruma Hizmetlerinde Koordinasyon Strateji Belgesi - CKHKSB, 2013) and about 500 executives and practitioners were trained on a new interagency coordination model in 2013. A field visit after about 15 months from the trainings indicated that a great number of these trained professionals were no longer engaging in relevant positions. In addition, approximately two years after the introduction of the aforementioned strategy document, there was no practical evaluation of its goals and activities (xxx, 2014). These are only some examples of how Turkey had struggled until the time of this research on sustaining and finalizing its previously introduced projects.

Consequently, this new effort towards establishing an effective administrative structure in child justice needed to be carried out in a sustainable manner. This would require effective planning on all fronts in this regard in consultation with other stake holders and a reliance on the scientific evaluation of the feasibility and/or effectiveness of these new implementation steps. In addition, populist and short-term perspectives need to be avoided for purposes of fostering sustainable practices.

\subsection{Propositions on the Functions of the New Administrative Structure.}

This research effort indicated that the most important matter in determining the bureaucratic structure and the desired level of an effective administration of the child justice processes in Turkey was to determine what functions would be carried out by the new administrative structure. The number and the nature of the functions assigned to the new administration would determine its bureaucratic structure and location. A significant focus of the research, therefore, was on what this new administrative structure should do as outlined by the study participants. The analysis of the qualitative data indicated the following functions should constitute the priorities of the new administrative structure.

3.2.1. Systematic Knowledge Production, Collection, and Distribution: An effective administration, according to the findings of this research, should facilitate research and development activities regarding child justice processes. In this regard, first, the new administrative structure should function as a hub to systematically collect and analyze official statistics and information produced by relevant agencies. Second, the new administration structure should assess the knowledge needs of practitioners. Based on these assessments it should either outsource research projects or carry out in-house research, depending on the nature and the extent of the research subject. Third, the knowledge produced or collected through several means should be effectively distributed and made available to interested parties. This function was considered especially vital in helping to develop evidence-based policies for improving the child justice system in Turkey.

3.2.2. Planning and Policy Development: As mentioned before, Turkey has already developed several strategic plans either directly or indirectly in the context of targeting child justice procedures. These plans, however, were not based on any effective evaluation process and were not prepared in coordination with other stake holders. As a consequence, there was no clear indication regarding these plans' achievements at the time of that research. The example regarding sustainability was included in this issue as detailed above. In addition to that example, another plan "National Strategy Document and Action Plan on Violence against Children" was prepared as a result of exhaustive efforts in 2013, in which this author was involved as the lead consultant. This action plan, however, could not be put into practice due to inconsistencies in the administration 
Buker, H., Gultekin, S., \& Akgul, A. (2019). Expected functions of an effective child justice system administration? A framework developed through a qualitative study in Turkey. Journal of Human Sciences, 16(1), 87-101. doi:10.14687/jhs.v16i1.5452

processes of relevant agencies (xxx, 2014b). Consequently, an effective administrative structure for the Turkish child justice system is expected to systematize planning and policy development functions from a holistic/systems perspective, and this function should include effective monitoring of the implementation of these plans and policies.

3.2.3. Organization: Organization is a term that refers to those broad functional actions required for guiding any administrative processes. Therefore, throughout the analysis of the data in this research effort, this function was intended to be made more specific. The data yielded three important roles expected from the implementation of an effective administrative structure in terms of organization: a) interagency coordination, b) acting as a focal point, and c) public relations.

First, an effective administrative structure in the Turkish child system was expected to facilitate interagency coordination and cooperation. Turkey had struggled in this regard since the enactment of the CPL in 2005. The lead role facilitating the coordination was transferred in 2011 from MoJ to MoFSP, which was a newly established ministry. Since this shift, there have been significant efforts made to achieve an effective coordination strategy among the relevant institutions in the child justice system, but the data in this research indicated that this had not been substantially achieved beyond maintaining routine meetings and reports. This issue, therefore, was among the prominent concerns of the research participants and appeared as an important theme regarding what was expected from an effective administration in the child justice system.

Secondly, the research participants indicated that there was no "owner" of the child justice system in Turkey. As of 2016, neither MoJ nor MoFSP had a special section regarding child justice. This situation had adverse outcomes especially when an external constituent (like a nongovernmental organization) wanted to discuss a problem or make a recommendation regarding the overall policies of the child justice system and could not find an official respondent. One of the participants indicated that a report prepared by an international agency could not be submitted to any governmental agency due to this very problem and could consequently not be utilized. In addition, the participants indicated that there was no active advocacy for policy development for the entire child justice procedures due to the lack of "ownership." Subsequently, another important role expected from an effective administrative structure was to act as a focal point for the entire Turkish child justice system.

Finally, the idea of an effective administration meant effective public relations for the research participants. As indicated above, there was a general lack of awareness among the Turkish society in regard to the rights, challenges, and needs of children going through the child justice processes (TBMM, 2010; T.C. Cumhurbaskanligi Devlet Denetleme Kurulu, 2013). Therefore, the public should be informed in a proper manner about what the child system is supposed to do in efforts to look out for the best interest of children in the society. Without proper public support, the child justice system will not be able to achieve its overall goals.

\subsubsection{Improving Human Resources}

Although the CPL requires specialization in the juvenile courts, the law enforcement systems and the child protection agencies of Turkey had not been able to retain a well-trained work force, as well as others, involved in carrying out child justice procedures. An effective administrative structure, hence, was expected to improve the quality of the human resources involved in this realm and to help retain that workforce to accomplish the overall goals of the child justice system. In this regard, the research indicated that the future needs were six fold: a) developing interactions through effective communication channels between the professionals working in the child justice system, b) assessing/planning the human resource needs of the system and informing the education and hiring policing accordingly, c) determining and maintaining professional standards for the actors of the child justice system, d) pursuing specialization in the relevant agencies by creating policies and rules for retaining experienced personnel, and finally e) planning and carrying out on-the-job training programs for improving the skills and knowledge of child justice professionals. 
Buker, H., Gultekin, S., \& Akgul, A. (2019). Expected functions of an effective child justice system administration? A framework developed through a qualitative study in Turkey. Journal of Human Sciences, 16(1), 87-101. doi:10.14687/jhs.v16i1.5452

3.2.5. Monitoring, Evaluation, and Feedback: This function should be specifically considered along with the coordination aspect of the organization function. In this regard, an effective administrative structure is supposed to constantly monitor the day-to-day processes of the system and evaluate its effectiveness towards the overall achievement of the system's goals. The most important example raised by the research participants concerning this function was about the implementation and monitoring of the protective and supportive measures as included in the CPL. The participants indicated that these measured decisions were not being properly monitored by the courts, as required by law. However, there was neither an effort to increase the courts' capacities in this regard, nor any insight provided to revise the existing processes to make them more beneficial for children. An effective administrative structure should monitor the overall operations in the system and evaluate their effectiveness in serving the best interests of children going through the child justice system. The outcome of monitoring/evaluation should not be disciplinary invasions towards individual agencies, but a set of recommendations to address the problems and the provision of relevant feedback on the root causes of the problems. Upon these, an individual system's agency should be able to initiate disciplinary and corrective actions, if deemed necessary.

\subsection{Propositions on the Bureaucratic Nature of the New Administrative Structure.}

The third important outcome of the data analysis was focused on several propositions regarding the bureaucratic nature of the new administrative structure in the Turkish child justice system. The research participants proposed quite different ideas on how and where this new administrative structure should be placed in the Turkish public administration system. At the time of this research Turkey had a parliamentary system in which the executive branch was under the responsibility of a prime minister and his/her cabinet consisted of different ministries. The most relevant ministries in this regard, as mentioned before, were the MoJ and MoFSP. Hence, the ideas of the participants ranged from constituting an agency under the Prime Ministry to maintaining an independent and over-the-top position for an effective administrative structure, to creating an agency under either of these ministries, to assigning new administrative responsibilities and authorities to some existing departments under either of these Ministries. Consequently, it was clear that the final decision would be highly affected by political concerns, rather than by the technical requirements of an ideal set of administrative functions.

Nonetheless, the overall research findings indicated several issues that should be taken into consideration in determining the bureaucratic nature of a new administrative structure as follows:

3.2.6. Organizational Location: Although the interviews indicated several options in this regard, the examination of the past experiences in the Turkish public administration realm raised several questions especially in regard to locating this new administrative structure as an independent board under the Prime Ministry. Although there are several boards (like Higher Board of Human Rights) in a similar bureaucratic location, they have not been considered as operational units with an effective and results oriented approach. Therefore, locating an administrative structure in a similar position may cause the failure of the expected outcomes.

The most optimal choice for Turkey, based on the past experiences and the current situation of the operations of the two major ministries seemed to be locating this agency under the Ministry of Justice (MoJ). MoJ's proximity with the child courts, even though the courts were constitutionally independent from the Ministry, its culturally observed power among the Turkish bureaucracy, and its well-established structure supported this position. The Child Courts constitute the backbone of the overall child justice system and an effective inclusion of them in any administrative function would be a significant determinant of its future success.

At the time of this research, the main distribution of responsibilities in the MoJ was through the General Directorates (GD). There were GDs for the Criminal and Civil Law related matters under the MoJ. Considering the nature of the overall child justice procedures, which might have both civil and criminal involvements, a new GD should be devoted solely to child justice matters. 
Buker, H., Gultekin, S., \& Akgul, A. (2019). Expected functions of an effective child justice system administration? A framework developed through a qualitative study in Turkey. Journal of Human Sciences, 16(1), 87-101. doi:10.14687/jhs.v16i1.5452

\section{Conclusion}

This research was intended to explore how to establish an effective administrative structure for the child justice system in Turkey. The overall outcome of the research indicated that in this effort, first and foremost important issue was to determine the founding principles of such an administrate structure. Secondly, it was deemed necessary to determine what the functions of such a new structure should be. A failure to determine these functions when working on this new structure's bureaucratic nature would not be meaningful. Lastly, determining some consensus regarding the bureaucratic nature and location of this structure was important, but the research revealed that this would mostly be affected by political considerations. Hence, emphasizing the founding principles and expected functions of an effective administrative structure seemed more reasonable than arguing about how and where such a structure should be located in the Turkish public administration system.

This research effort followed an inductive approach, at the end of which a framework of a model for an effective administrative structure in the Turkish child justice system was set forth. However, the practicality of this model needs to be tested with further research especially by employing survey methods with more participants representing the relevant population that should include both governmental and non-governmental parties. In addition, the contribution of children should also be sought with appropriate strategies.

Although this research was conducted in a Turkish context, the framework developed in regard to establishing an effective child administration structure may be utilized in other countries where the child justice processes are still in their infancy and not working within a well-established systems approach. Further research should explore the adoptability of this approach in developing an effective child justice administration in different countries.

\section{Bibliography}

ASQ, (2016) W. Edgar Deming's 14 Points for Total Quality Management. Available at: http://asq.org/learn-about-quality/total-quality-management/overview/demingpoints.html

Bertalanffy LV (1968) General System Theory. New York: George Braziller.

xxx (2014). Final Report of the National Individual Consultancy Services for "Up-Scaling the National Coordination Strategy. Ankara: UNICEF - TURKEY.

xxx (2014 b) The Final Draft of the National Strategy Document and Action Plan on Violence against Children. Ankara: UNICEF - TURKEY.

(2014) Cocuk Adaletinde Surec Akis Semalari. UNICEF Turkey Office.

(2013) Cocuk Koruma Hirmetlerinde Koordinasyon Strateji Belgesi - CKHKSB. Available at: http://cocukhizmetleri.aile.gov.tr/data/558275b7369dc544742aae8f/KSB\%20(26.02.201 $4) \% 20(2) \cdot p d f$

Dimock ME and Dimock G (1983) Public Administration, 5th Ed. Holt: McDougal.

Easen P, Atkins M and Dyson A (2000) Interprofessional collaboration and conceptualisations of practice. Children and Society 14(5): 355-367.

Fayol H (1949) General and Industrial Management. London: Sir Isaac Pitman \& Sons.

Flynn CC and Harbin GL (1987) Evaluating Interagency Coordination Efforts Using a Multidimensional, Interactional, Developmental Paradigm. Remedial and Special Education, 35-44.

Goering, P., \& Rogers, J. (1986). A model for planning interagency coordination. Canada's Mental Health 8(3): 5-8.

Gulick LH (1936) Notes on the Theory of Organization. In L. G. Urwick, Papers on the Science of Administration, pp. 3-35). New York: Institute of Public Administration. 
Buker, H., Gultekin, S., \& Akgul, A. (2019). Expected functions of an effective child justice system administration? A framework developed through a qualitative study in Turkey. Journal of Human Sciences, 16(1), 87-101. doi:10.14687/jhs.v16i1.5452

Kahn, D., \& Katz, R. L. (2010). Organizations and the System Concept. In J. M. Shafritz, Classics of Organization Theory. Belmont, CA: Wadsworth, pp. 17-33.

Kirimsoy E, Acar H, Yokus H, Kaynak H, Aydin M, Antakyalioglu S, Acar YB (2013) Cocuk Adalet Sistemi Calisanlari Egitim Programi - Hukukcular Icin Egitim Kitabi. Ankara: Adalet Bakanligi/ UNICEF. Aavailable at: http://www.unicef.org.tr/files/bilgimerkezi/doc/5.\%20HUKUK $\%$ C3\%87ULAR $\% 20 \%$ C4\%B0\%C3\%87\%C4\%B0N $\% 20 \mathrm{E} \% \mathrm{C} 4 \% 9 \mathrm{E} \% \mathrm{C} 4 \% \mathrm{~B} 0 \mathrm{~T} \% \mathrm{C} 4 \% \mathrm{~B} 0 \mathrm{M} \% 20 \mathrm{~K} \% \mathrm{C} 4 \% \mathrm{~B} 0 \mathrm{TA}$ BI.pdf

O'Leary R (2010) The Future of Public Administration around the World: The Minnowbrook Perspective. Washington, DC: Georgetown University Press.

Riley AL (1994) Interagency coordination: The key to mainstreaming children with special needs into day care. Pediatrics 94(6): 1059-1061.

Rivard J and Morrissey J (2003) Factors associated with interagency coordination in a child mental health service system demonstration. Adm Policy Ment Health 30(5): 397-415.

T.C. Cumhurbaskanligi Devlet Denetleme Kurulu (2013) Merkęi ve yerel kamu kurum ve kuruluslar ile sivil toplum kuruluşlarmm, kadın ve çocuklara yönelik şiddetle mücadele kapasite ve imkânlarmm degerlendirilmesi. Ankara, Turkey: TC Cumhurbaskanligi. Available at: http://www.tccb.gov.tr/assets/dosya/ddk55.pdf

TBMM (2010) Kayn Çocuklar Başta Olmak Üzere Çocuklarm Mağdur Olduğu Sorunlarn Arastirlarak Alınması Gereken Önlemlerin Belirlenmesi Amacyla Kurulan Meclis Arastirmasi Komisyonu Raporu. Ankara, Turkey:

TBMM. Availablehttps://www.tbmm.gov.tr/sirasayi/donem23/yil01/ss589.pdf

UNICEF (n.d.) Cocuklar icin Adalet Projesi Videolar. Available at: https://youtu.be/tMDViJXBMNc?list=UUJslXkLWJYvfCXDOylgkWsw

Yalcinkaya M (2002) Acik Sistem Teorisi ve okula uygulanmasi. G.U. Egitim Fakultesi Dergisi 22(2): 103-116. 